\title{
In vitro assessment of phytochemicals, antioxidant and DNA protective potential of wild edible fruit of Elaeagnus latifolia Linn.
}

\author{
Sourav PANJA ${ }^{1}$, Dipankar ChaUdhuRI ${ }^{1}$, Nikhil BabAn GHATE ${ }^{1}$, Ha Le MinH ${ }^{2}$, Nripendranath MANDAL ${ }^{1 *}$
}

${ }^{1}$ Div. Mol. Med., Bose Inst., P-1/12 C.I.T. Scheme VII-M, Kolkata-700054, India, mandaln@rediffmail.com, nripen@jcbose.ac.in

${ }^{2}$ Lab. Pharm. Chem., Inst.Nat. Prod. Chem., Vietnam Acad. Sci. Technol., 18 Hoang Quoc Viet Street, Hanoi, Vietnam

${ }^{*}$ Correspondence and reprints

Received 30 September 2013 Accepted 17 January 2014

Fruits, 2014, vol. 69, p. 303-314 (C) 2014 Cirad/EDP Sciences All rights reserved

DOI: 10.1051/fruits/2014019 www.fruits-journal.org

RESUMEN ESPAÑOL, p. 314
In vitro assessment of phytochemicals, antioxidant and DNA protective potential of wild edible fruit of Elaeagnus latifolia Linn.

Abstract - Introduction. Elaeagnus latifolia Linn. is a type of wild edible fruit found in northeast India, Thailand and also in Vietnam. Although the fruit is reported to be a source of vitamins, minerals, essential fatty acids and other bioactive compounds, only a few studies have been concerned with the antioxidant activity of this plant. Materials and methods. Our study revealed in vitro antioxidant and free radical scavenging activity of $70 \%$ methanolic extract of Elaeagnus latifolia Linn. (ELME). Various tests including identification and quantification of phytochemicals, total antioxidant activity, hydroxyl radical, superoxide radical, singlet oxygen, hypochlorous acid scavenging, reducing power and DNA protection assays were performed. Results and discussion. Among the tests, ELME scavenged superoxide radical $\left[\mathrm{IC}_{50}=(150.78 \pm\right.$ 4.2) $\left.\mu \mathrm{g} \cdot \mathrm{mL}^{-1}\right]$, hydroxyl radical $\left[\mathrm{IC}_{50}=(238.09 \pm 11.63) \mu \mathrm{g} \cdot \mathrm{mL}^{-1}\right]$ and protected pUC18 DNA $\left[\mathrm{P}_{50}=(695.91 \pm 15.84) \mu \mathrm{g} \cdot \mathrm{mL}^{-1}\right] ; \mathrm{P}_{50}$ signifies the concentration for $50 \%$ protection. The fruit is found to be a source of minute amounts of carbohydrates, ascorbic acid, tannins, phenolics and flavonoids. HPLC data showed that purpurin, tannic acid, quercetin, catechin, reserpine and rutin are present in ELME. Conclusion. Our results provide evidence that $70 \%$ methanol extract of E. latifolia Linn. acts as a promising antioxidant as well as DNA protector, which is partly due to the phenolic and flavonoid compounds present in it.

India / Elaeagnus latifolia / fruits / medicinal properties / free radicals / antioxidants

Évaluation in vitro des composés phytochimiques, des antioxydants et du potentiel protecteur de I'ADN des fruits sauvages comestibles d'Elaeagnus latifolia Linn.

Résumé - Introduction. Elaeagnus latifolia Linn. est un type de fruit sauvage comestible trouvé dans le nord de l'Inde, en Thailande et également au Vietnam. Bien que le fruit soit signalé comme une source de vitamines, minéraux, acides gras essentiels et autres composés bioactifs, seules quelques recherches ont porté sur l'activité antioxydante de cette plante. Matériel et méthodes. Notre étude a révélé l'activité antioxydante et le potentiel de piégeage des radicaux in vitro de pulpe d'Elaeagnus latifolia Linn. extraite à l'aide d'une solution aqueuse de méthanol à $70 \%$ (ELME). Divers tests, dont l'identification et la quantification de composés phytochimiques, de l'activité totale antioxydante, du radical hydroxyle, du radical superoxyde et de l'oxygène singulet, et des essais du pouvoir réducteur et de piégeage de l'acide hypochloreux et de la protection de l'ADN ont été effectués. Résultats et discussion. Parmi les tests réalisés, le radical superoxyde piégé de ELME $\left[\mathrm{IC}_{50}=(150.78 \pm 4.2) \mu \mathrm{g} \cdot \mathrm{mL}^{-1}\right]$, le radical hydroxyle $\left[\mathrm{IC}_{50}=(238.09 \pm\right.$ 11.63) $\left.\mu \mathrm{g} \cdot \mathrm{mL}^{-1}\right]$ et l'ADN pUC18 protégé $\left[\mathrm{P}_{50}=(695.91 \pm 15.84) \mu \mathrm{g} \cdot \mathrm{mL}^{-1}\right]$ ont présenté une protection efficace. Le fruit se trouve être une source d'infimes quantités d'hydrates de carbone, d'acide ascorbique, de tanins, de composés phénoliques et de flavonoïdes. Les données HPLC ont montré que la purpurine, l'acide tannique, la quercétine, la catéchine, la réserpine et la rutine étaient présents dans les extraits (ELME) présents. Conclusion. Nos résultats fournissent la preuve que l'extrait d'E. latifolia Linn. agit comme un antioxydant prometteur et comme un protecteur de l'ADN, ce qui est dû en partie aux composés phénoliques et flavonoïdes qui le composent.

Inde / Elaeagnus latifolia / fruit / propriété pharmacologique / radical libre / antioxydant 


\section{Introduction}

A number of reactive oxygen species and reactive nitrogen species are essential parts of aerobic life and metabolism [1]. Reactive oxygen species (ROS) directly bring about damage of cellular macromolecules, especially DNA, which undergo strand breakage, and change and release of bases as well as modification of sugar moieties [2, 3], thus promoting a series of pathological events, viz. cancer and ageing [4]. On the other hand, ROS along with pro-oxidants give rise to emphysema, cirrhosis, arteriosclerosis, inflammation, genotoxicity and other disease conditions [5]. Various food products as well as beverages containing antioxidants act through different mechanisms, such as scavenging and chelating metals that catalyse the formation of free radicals, thus being important for the human body due to their ability to counteract oxidative damage [6, 7]. Synthetic antioxidants such as butylated hydroxyanisole (BHA) and butylated hydroxyltoluene (BHT) have been restricted for use due to their possible toxicological effects [8]. Therefore, the search for natural antioxidants has received much attention in order to identify and develop more potent natural antioxidants to replace synthetic ones.

Elaeagnus latifolia Linn. is a type of edible fruit; it belongs to the Elaeagnaceae family. Elaeagnus latifolia is a deciduous shrub growing to a maximum height of $3 \mathrm{~m}(9 \mathrm{ft})$ and expands maximally to $3 \mathrm{~m}(9 \mathrm{ft})$ with a growing speed of medium rate. It is hardy to zone 9 (can tolerate a minimum temperature of $-7^{\circ} \mathrm{C}$ ) and not frost-tender. It is found in northeast India, Thailand and also in Vietnam. It is commonly known as SohShang in Meghalya, Sibsagar (Dikho valley of Assam), in India. The flowers are hermaphrodite (have both male and female organs) and are pollinated by bees.It can fix nitrogen. The fruit is oblong in shape with a dark pink colour at the time of ripening. The fruits are eaten raw as well as used for making chutney, jam, jelly and refreshing drinks [9]. The fruit is a plentiful source of vitamins, minerals and other bioactive compounds. It is also a source of essential fatty acids, which is fairly unusual for a fruit [9].
The objective of our study was to evaluate the phytochemical constituents, antioxidant potential, free radical scavenging activity and DNA protection activity of $70 \%$ methanolic extract of Elaeagnus latifolia fruit (ELME).

\section{Materials and methods}

\subsection{Chemicals}

2,2'-azinobis-(3-ethylbenzothiazoline-6-sulphonic acid) (ABTS) was procured from Roche Diagnostics, Mannheim, Germany, and 6-hydroxy-2,5,7,8-tetramethylchroman2-carboxylic acid (Trolox) was obtained from Fluka, Buchs, Switzerland. Potassium persulphate $\left(\mathrm{K}_{2} \mathrm{~S}_{2} \mathrm{O}_{8}\right)$, 2-deoxy-2-ribose, ethylene diamine tetra acetic acid (EDTA), ascorbic acid, trichloroacetic acid (TCA), mannitol, nitro blue tetrazolium (NBT), reduced nicotinamide adenine dinucleotide (NADH), phenazine methosulphate (PMS), sodium nitroprusside (SNP), 1,10-phenanthroline, sulphanilamide, naphthyl ethylenediamine dihydrochloride (NED), L-histidine, lipoic acid, sodium pyruvate, quercetin and ferrozine were obtained from Sisco Research Laboratories Pvt. Ltd., Mumbai, India. HPLC-grade acetonitrile, ammonium acetate, hydrogen peroxide, potassium hexacyanoferate, Folin-Ciocalteu reagent, sodium carbonate, mercuric chloride, potassium iodide, anthrone, vanillin, thiourea, 2,4-dinitro phenylhydrazine, sodium hypochlorite, aluminium chloride, xylenol orange, butylated hydroxytoluene (BHT) and N,N- dimethyl4-nitrosoaniline were obtained from Merck, Mumbai, India. 1,1-diphenyl-2-picrylhydrazyl (DPPH), gallic acid, (+) catechin and curcumin were obtained from MP Biomedicals, France. Catalase, reserpine and sodium bicarbonate were obtained from HiMedia Laboratories Pvt. Ltd., Mumbai, India. Evans blue was purchased from BDH, England. Dglucose was procured from Qualigens Fine Chemicals, Mumbai. Diethylene triamine pentaacetic acid (DTPA) was obtained from Spectrochem Pvt. Ltd., Mumbai, India. Thiobarbituric acid (TBA) was obtained from Loba Chemie, Mumbai, India. 


\subsection{Animals}

The Animal Ethical Clearance Committee of the Institute (registration number: 95/1999/ CPCSEA) approved the use of adult male Swiss Albino mice (Mus musculus), weighing 20-25 g, for experimentation. Each polypropylene cage contained four mice at a time, supplied with an ad libitum laboratory diet and water at $(25 \pm 2){ }^{\circ} \mathrm{C}$ and $(60 \pm 5) \%$ humidity and a normal photocycle (12 h dark / 12 h light).

\subsection{Plant material and extract preparation}

The fruits of E. latifolia were collected from the Garo Hills market in Assam (India). The flesh pulps of fruit (100 g) were stirred using a magnetic stirrer with $70 \%$ of methanol in water $(1000 \mathrm{~mL})$ for $15 \mathrm{~h}$; the mixture was centrifuged at $2850 \times g$ and the supernatant decanted. The process was repeated by adding the solvent to the precipitated pellet. The supernatants were concentrated in a rotary evaporator and lyophilised. The yield of fruit in methanolic extract was $7.89 \%$. Lyophilised E. latifolia $70 \%$ methanolic extract was stored at $-20{ }^{\circ} \mathrm{C}$ until use.

\subsection{Phytochemical analysis}

Standard qualitative methods as described previously were carried out in order to investigate the resident phytochemicals such as phenols, flavonoids, alkaloids, carbohydrates, ascorbic acid, saponins, tannins, terpenoids, triterpenoids, anthraquinones and glycosides in the extract $[10,11]$.

\subsubsection{Determination of total phenolic content}

According to a previously described protocol [12], the total phenolic content of ELME was determined by Folin-Ciocalteu (FC) reagent. All tests were performed six times. The phenolic content was calculated from a gallic acid standard curve containing eight points.

\subsubsection{Determination of total flavonoids}

Total flavonoid content was determined according to a previously discussed method [12]. The flavonoid content was calculated from a quercetin standard curve containing six points.

\subsubsection{Quantification of alkaloid content}

Quantification of alkaloid content for ELME was carried out using a method described earlier [13]. All tests were performed six times. The alkaloid content was evaluated from the reserpine standard graph containing nine points.

\subsubsection{Quantification of carbohydrate content}

The carbohydrate content of the extract was quantified using a previously described method [13]. All tests were performed six times. The carbohydrate content was evaluated from a glucose standard curve containing six points.

\subsubsection{Quantification of ascorbic acid content}

This quantification was carried out according to a previously described method [13]. All tests were performed six times. The ascorbic acid content was evaluated from an L-ascorbic acid standard curve containing eight points.

\subsubsection{Quantification of tannin content}

This was assayed and performed as per a previously described method [14]. All tests were performed six times. The tannin content was evaluated from a catechin standard graph containing six points.

\subsection{High-Performance Liquid Chromatography (HPLC) standardisation of the extract}

For HPLC analysis, stock solutions $\left(10 \mu \mathrm{g} \cdot \mathrm{mL}^{-1}\right)$ were prepared in the mobile phase for the sample (ELME) [15] and purpurin, tannic acid, quercetin, catechin, reserpine and rutin as standards. Samples were then filtered through a $0.45-\mu \mathrm{m}$ polytetrafluoroethylene (PTFE) filter (Millipore) to remove any particulate matter. Analysis was performed using a HPLC Prominence System RF10AXL (Shimadzu Corp., Japan) equipped with a degasser (DGU-20A5), quaternary pump (LC-20AT), auto-sampler 
(SIL-20A) and reflective index (RID-10A), fluorescence (RF-10AXL) and diode array (SPD-M20A) detectors. Twenty $\mu \mathrm{L}$ of sample and standards were injected and analysed in triplicate. Gradient elution consecutive mobile phases of acetonitrile and $0.5 \mathrm{mM}$ ammonium acetate in water, at a flow rate of $1 \mathrm{~mL} \cdot \mathrm{min}^{-1}$ for $65 \mathrm{~min}$ through the column (Z1C-HILIC), were maintained at $25^{\circ} \mathrm{C}$. The detection was carried out at $254 \mathrm{~nm}$.

\subsection{In vitro antioxidant and free radical scavenging assays}

\subsubsection{Total antioxidant activity}

The antioxidant capacity of the ELME (0.05$10 \mathrm{mg} \cdot \mathrm{mL}^{-1}$ ) was evaluated by $\mathrm{ABTS}^{+}$radical cation decolourisation assay in comparison with the Trolox standard [16]. Their absorbance was measured at $734 \mathrm{~nm}$.

\subsubsection{DPPH radical scavenging assay}

Complementary data supporting the study of the antioxidant potential of ELME were provided by the DPPH radical scavenging assay [12]. The sample sets were then spectrophotometrically measured at $517 \mathrm{~nm}$ after $2 \mathrm{~min}$. All the above tests were performed six times and in each case the percentage of scavenging of the respective radical was calculated using the following equation: \% scavenging $=\left[\left(\mathrm{A}_{0}-\mathrm{A}_{1}\right) / \mathrm{A}_{0}\right] \times$ 100 , where $A_{0}$ is the absorbance of the control, and $\mathrm{A}_{1}$ is the absorbance in the presence of the sample of fruit extracts and the standard.

\subsubsection{Hydroxyl radical scavenging assay}

The hydroxyl radical scavenging assay was performed as described previously; it is based on the Fenton reaction [17]. Mannitol, a classical OH. scavenger, was used as a positive control.

\subsubsection{Superoxide radical scavenging assay}

The scavenging activity of the superoxide radical for the ELME $\left(0-120 \mu \mathrm{g} \cdot \mathrm{mL}^{-1}\right)$ was measured spectrophotometrically at $562 \mathrm{~nm}$ as described previously [17]. Quercetin was used as a standard.

\subsubsection{Nitric oxide radical scavenging assay}

Nitric oxide (NO) generated from the SNP aqueous solution at physiological $\mathrm{pH}$ interacts with oxygen to produce nitrite ions, which were measured by Griess-Illosvoy reaction [12]. Various doses of ELME $\left(0-70 \mu \mathrm{g} \cdot \mathrm{mL}^{-1}\right)$ along with the standard curcumin were assessed for their respective activities.

\subsubsection{Peroxynitrite radical scavenging assay}

Peroxynitrite $\left(\mathrm{ONOO}^{-}\right)$was synthesised $12 \mathrm{~h}$ before the experiment, as described by Beckman et al. [18]. The scavenging activity of the extract $\left(0-200 \mu \mathrm{g} \cdot \mathrm{mL}^{-1}\right)$ was compared with that of the reference compound gallic acid.

\subsubsection{Singlet oxygen radical scavenging assay}

The production of singlet oxygen $\left({ }^{1} \mathrm{O}_{2}\right)$ was determined by monitoring N,N-dimethyl-4nitrosoaniline (RNO) bleaching using a previously reported method [14]. The scavenging activity of the extract $\left(0-200 \mu \mathrm{g} \cdot \mathrm{mL}^{-1}\right)$ was compared with that of the standard lipoic acid.

\subsubsection{Hypochlorous acid scavenging assay}

The hypochlorous acid scavenging assay was carried out as described previously [12]. The scavenging activity of the extract $(0-$ $100 \mu \mathrm{g} \cdot \mathrm{mL}^{-1}$ ) and the standard ascorbic acid was evaluated by measuring the decrease in absorbance of catalase at $404 \mathrm{~nm}$.

\subsection{9. $\mathrm{Fe}^{2+}$ chelation activity}

The iron-chelating capacity of ELME (0$120 \mu \mathrm{g} \cdot \mathrm{mL}^{-1}$ ) was spectrophotometrically evaluated at $562 \mathrm{~nm}$ as described earlier [12]. EDTA was used as a positive control.

\subsubsection{Lipid peroxidation assay}

The ability of ELME to inhibit lipid peroxidation was assayed by a previously described method [17]. Various concentrations of the extract $\left(2.5-25 \mu \mathrm{g} \cdot \mathrm{mL}^{-1}\right)$ were assessed along with the standard Trolox. 
The absorbance of the reaction mixtures was taken at $532 \mathrm{~nm}$.

\subsubsection{Measurement of reducing power}

The $\mathrm{Fe}^{3+}$ reducing power of the extract was determined by a method performed earlier [17]. Various concentrations $\left(0-1.0 \mathrm{mg} \cdot \mathrm{mL}^{-1}\right)$ of the extract were tested and their absorbance was measured at $700 \mathrm{~nm}$ against an appropriate blank.

\subsubsection{DNA protection assay}

The protection of the pUC18 plasmid DNA, damaged by Fenton reaction-generated $\mathrm{OH}$ radicals, was studied by quantifying the decrease in supercoiled DNA after oxidative attack using a previously described method with minor modifications [19]. Briefly, $\mathrm{FeSO}_{4}$ solution $(15 \mu \mathrm{M})$, extract of varying doses, DNA ( $1 \mu \mathrm{g})$ and water were added to Hepes buffer ( $\mathrm{pH} 7.2,13 \mathrm{mM}$ ) to make an initial reaction mixture. $\mathrm{H}_{2} \mathrm{O}_{2}$ solution $(0.0125 \mathrm{mM})$ was then added to start the reaction. After $10 \mathrm{~min}$, the reaction was stopped by adding desferal $(0.2 \mathrm{mM})$ as a stopping reagent. Twenty $\mu \mathrm{L}$ of each reaction mixture was loaded in 1\% agarose gel. After electrophoresis, the gel was stained with ethidium bromide $\left(1 \mu \mathrm{g} \cdot \mathrm{mL}^{-1}\right)$ and visualised in a UV transilluminator. The DNA bands were quantified through densitometry and the following formula was used to calculate the percentage of protection: $\% \mathrm{SC}=$ $\{1.4 \times \mathrm{SC} /[\mathrm{OC}+(1.4 \times \mathrm{SC})] \times 100\}$, where $\mathrm{SC}=$ supercoiled; $\mathrm{OC}=$ open circular; 1.4 $=$ correction factor $\%$ protection $=100 \times$ [(control SC - chelator SC)/(control SC - no chelator SC) - 1]

The ability of the fruit extract to protect the DNA supercoil can be expressed by the concentration of sample required for $50 \%$ protection, designated as the $P_{50}$ value.

\subsubsection{Statistical analysis}

All data were reported as the mean \pm standard deviation of six measurements. The statistical analysis was performed by KyPlot version 2.0 beta 13 (32 bit) and was plotted graphically by Origin professional 8.0, wherever necessary. The $\mathrm{IC}_{50}$ values were calculated by the formula: $Y=100 \times\left[\mathrm{A}_{1} /(X+\right.$ $\left.\mathrm{A}_{1}\right)$ ], where $\mathrm{A}_{1}=\mathrm{IC}_{50}, \quad Y=$ response
( $Y=100 \%$ when $X=0$ ) and $X=$ inhibitory concentration. The $\mathrm{IC}_{50}$ values were compared by paired $t$-test (two-sided) and onesided ANOVA; wherever required, $P<0.05$ was considered significant.

\section{Results and discussion}

In physiological systems, the oxidation chain reaction produces many free radicals which disrupt biomolecules and can disrupt the immune system [20]. Antioxidants terminate these chain reactions by removing free radical intermediates and inhibit other oxidation reactions. Previously, it was reported that the various types of edible fruits have antioxidant activity [21, 22]. It would be better if dietary food supplements were a potent source of antioxidants. Our study focused on the evaluation of the antioxidant and free radical scavenging activity of ELME.

\subsection{Phytochemical analysis}

Our study showed that all phytochemicals are moderately present in ELME except alkaloids, saponins and glycosides. The total phenolic, flavonoid, ascorbate and tannin contents of ELME were calculated (table I). Phenolic compounds are very important plant constituents due to their ability to confer free radical scavenging [23]. Moreover, flavonoids show their antioxidant properties through scavenging or chelating processes [24]. Different types of carbohydrates give rise to different glycemic responses and they are also able to stimulate lipogenesis [25]. In addition, ascorbic acid, terpenoids and triterpenoids are good antioxidant phytoconstituents. Tannins show internal antiseptic, anti-diarrhoea, antimicrobial and antifungal effects and also have astringent properties [26]. Anthraquinones protect from Alzheimer's disease [27]. The results strongly suggest that phenolics are important components of these plants. The other phenolic compounds such as flavonoids, which contain hydroxyls, are responsible for the radical scavenging effect in the plants. According to our study, the moderate content of carbohydrate, ascorbate, tannin, 
Table I.

Qualitative and quantitative phytochemical analysis of $70 \%$ methanolic extract of Elaeagnus latifolia Linn. (ELME).

\begin{tabular}{|c|c|c|c|c|}
\hline \multicolumn{5}{|c|}{ Quantitative analyses: results are given for 100 mg extract } \\
\hline $\begin{array}{l}\text { Total phenolics } \\
\text { (mg gallic acid Eq) }\end{array}$ & $\begin{array}{l}\text { Total flavonoids } \\
\text { (mg quercetin Eq) }\end{array}$ & $\begin{array}{c}\text { Total ascorbate } \\
\text { (mg ascorbic acid Eq) }\end{array}$ & $\begin{array}{l}\text { Carbohydrates } \\
\text { (mg glucose Eq) }\end{array}$ & $\begin{array}{c}\text { Tannins } \\
\text { (mg catechin Eq) }\end{array}$ \\
\hline $7.04 \pm 0.27$ & $5.44 \pm 0.16$ & $0.23 \pm 0.09$ & $10.96 \pm 0.08$ & $0.20 \pm 0.03$ \\
\hline \multicolumn{5}{|l|}{ Qualitative analyses } \\
\hline Alkaloids & Terpenoids & Triterpenoids & Anthraquinones & Glycosides \\
\hline Absence & Presence & Presence & Presence & Absence \\
\hline
\end{tabular}

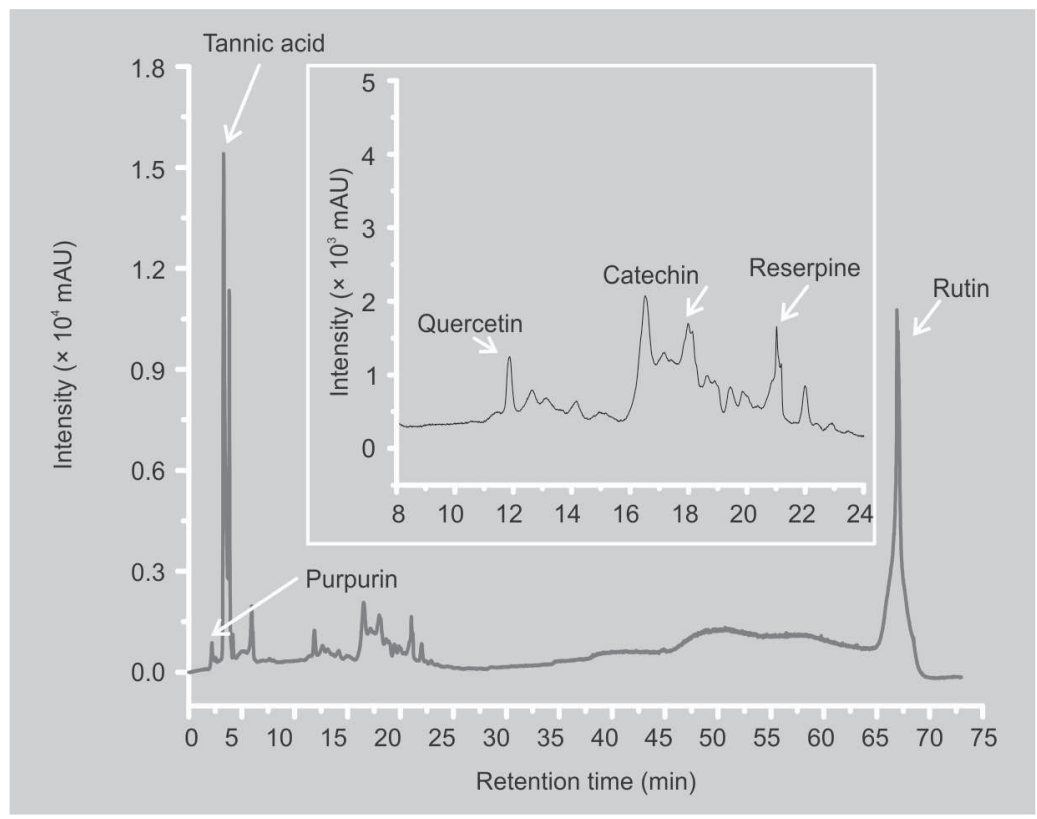

Figure 1.

HPLC chromatogram of $70 \%$ methanolic extract of

Elaeagnus latifolia Linn (ELME). Inset shows expanded region of the chromatogram with the retention time of 8-24 $\mathrm{min}$. terpenoids and triterpenoids also in E. latifolia can explain their good radical scavenging activity. Our study carried out on ELME revealed the presence of medically active constituents.

\subsection{HPLC standardisation of ELME}

Moreover, HPLC analysis was performed to identify the presence of bioactive compounds in ELME by comparing with the respective retention time of the reference standards. The chromatogram obtained from HPLC analysis of the extract and six main peaks with retention times at (2.17,
$3.35,11.86,18.00,21.05$ and 66.91) min corresponded to those of purpurin, tannic acid, quercetin, catechin, reserpine and rutin, respectively (figure 1). It has been previously reported that these six compounds have antioxidant properties [28-32].

\subsection{Total antioxidant activity}

The total antioxidant activity of the extract was determined based on the decolourisation of the $\mathrm{ABTS}^{+}$produced by reaction of ABTS with potassium persulphate and measured spectrophotometrically at $734 \mathrm{~nm}$. The addition of ELME and Trolox convert this preformed radical cation into ABTS in a concentration-dependent manner. The interaction of the $\mathrm{ABTS}^{+}$with the extract or the standard Trolox results in suppression of this cation and are plotted as percentage inhibition of absorbance (figure 2). The TEAC value of the extract was measured as $0.070 \pm 0.003$ (table II). The TEAC value obtained reflects the antioxidant potency of the extract.

\subsection{DPPH scavenging assay}

The DPPH stable free radical method is an easy, rapid and sensitive way to survey the antioxidant activity of a specific compound or plant extracts [33]. According to our results, it is evident that ELME scavenges DPPH radical moderately as compared with the ascorbic acid (figure 3, table II). The $\mathrm{IC}_{50}$ values of ELME and the standard were found 
to be $(134.31 \pm 8.39) \mu \mathrm{g} \cdot \mathrm{mL}^{-1}$ and $(5.29 \pm$ $0.28) \mu \mathrm{g} \cdot \mathrm{mL}^{-1}$, respectively, which show that ELME possesses a higher scavenging activity than water methanolic extract of another species of Elaeagnus (E. pyriformis) [34].

The effect of the plant extract in the scavenging assay of DPPH radical furthermore confirmed the fact that the extract acts as an antioxidant, since the studies of TEAC and DPPH scavenging can be observed as complementary to each other.

\subsection{Hydroxyl radical scavenging assay}

The most detrimental of the free radicals formed in biological systems is the hydroxyl radical that causes enormous damage to biomolecules of the living cells [35]. This compound forms a pink chromogen upon heating with TBA at low pH. As ELME or standard mannitol was added to the reaction mixture the hydroxyl radicals were scavenged and thereby sugar damage can be blocked (figure 4). The $\mathrm{IC}_{50}$ values (table II) of ELME and the standard in this assay were $(238.09 \pm 11.63) \mu \mathrm{g} \cdot \mathrm{mL}^{-1}$ and $(571.45 \pm$ 20.12) $\mu \mathrm{g} \cdot \mathrm{mL}^{-1}$, respectively. The results indicate that ELME is an excellent hydroxyl radical scavenger; it is better than the standard mannitol.

\subsection{Superoxide scavenging assay}

Superoxide anion is a harmful reactive oxygen species (ROS) with a detrimental effect on the cellular components in biological systems [36]. Plant-derived antioxidants exert their effects by enhancing the level of antioxidant enzymes such as superoxide dismutase or by lowering the levels of lipid peroxides in the blood or liver [37]. The extract and the reference compound quercetin have the ability to quench superoxide radicals in the PMS-NADH reaction mixture (figure 5). The $\mathrm{IC}_{50}$ values (table II) of the fruit extract and quercetin were (150.78 \pm 4.2) $\mu \mathrm{g} \cdot \mathrm{mL}^{-1}$ and $(42.06 \pm 1.35) \mu \mathrm{g} \cdot \mathrm{mL}^{-1}$, respectively. The extract is not more potent than the standard, yet a scavenger of superoxide radical.

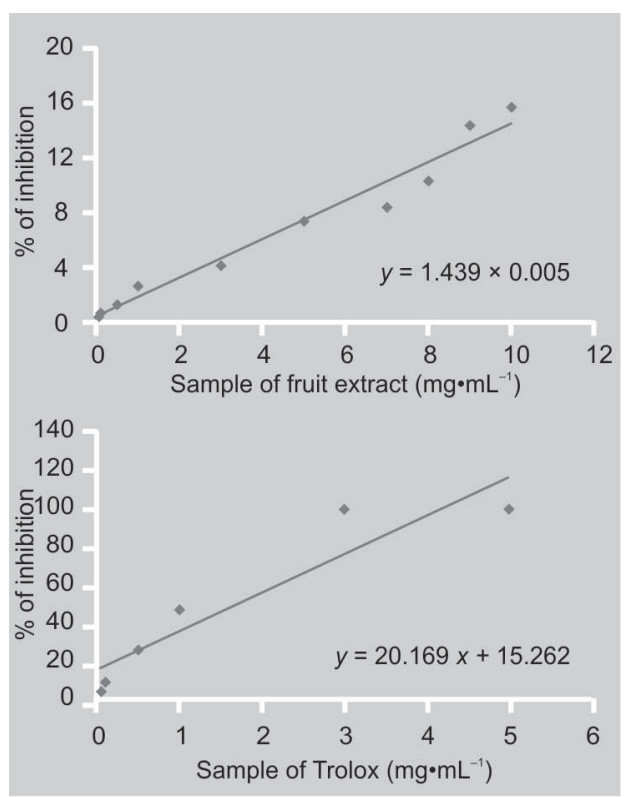

\subsection{Hypochlorous acid scavenging assay}

At the sites of inflammation, the neutrophil enzyme myeloperoxidase oxidises $\mathrm{Cl}$ - ions and produces another harmful ROS, hypochlorous acid, which reacts with various types of biomolecules including nucleic acid, lipid and protein [36, 38, 39]. The dosedependent hypochlorous acid scavenging activity of ELME was compared with that of ascorbic acid (figure 6 ). The $\mathrm{IC}_{50}$ value was $(667.11 \pm 6.56) \mu \mathrm{g} \cdot \mathrm{mL}^{-1}$; it was higher than that of ascorbic acid $\left[(235.95 \pm 5.75) \mu \mathrm{g} \cdot \mathrm{mL}^{-1}\right]$ (table II). The inhibition of catalase deactivation in the presence of ELME indicates its $\mathrm{HOCl}$ scavenging activity. So, from our results, it could be anticipated that ELME is a moderate $\mathrm{HOCl}$ scavenger but not as good as ascorbic acid.

\section{8. $\mathrm{Fe}^{2+}$ chelation activity}

The results demonstrated that the formation of the $\mathrm{Fe}^{2+}$-ferrozine complex is inhibited in the presence of test and reference compounds (figure 7 ). The $\mathrm{IC}_{50}$ values of the ELME and EDTA were (993.68 \pm $50.74) \mu \mathrm{g} \cdot \mathrm{mL}^{-1}$ and $(1.27 \pm 0.05) \mu \mathrm{g} \cdot \mathrm{mL}^{-1}$, respectively (table II). According to the
Figure 2.

Total antioxidant activity of fruit extract and Trolox in the ABTS radical cation decolourisation assay. All data are expressed as mean \pm S.D. $(n=6)$. 


\begin{tabular}{|c|c|c|c|}
\hline Activity & Values for ELME ${ }^{1}$ & Standard & Values of standard compounds \\
\hline TEAC value & $0.070 \pm 0.003$ & - & - \\
\hline DNA protection, $[\mathrm{P}]_{50}$ & $695.91 \pm 15.84$ & - & - \\
\hline \multicolumn{4}{|l|}{$\mathrm{IC}_{50}$ values for the activities of ELME in } \\
\hline DPPH scavenging & $134.31 \pm 8.39$ & Ascorbic acid & $5.29 \pm 0.28^{\star \star \star}$ \\
\hline Hydroxyl radical $(\mathrm{OH} \cdot)$ scavenging & $238.09 \pm 11.63$ & Mannitol & $571.45 \pm 20.12^{\star \star \star}$ \\
\hline Superoxide anion $\left(\mathrm{O}_{2}{ }^{-}\right)$scavenging & $150.78 \pm 4.20$ & Quercetin & $42.06 \pm 1.35^{\star \star \star}$ \\
\hline Hypochlorous acid ( $\mathrm{HOCl})$ scavenging & $667.11 \pm 6.56$ & Ascorbic acid & $235.95 \pm 5.75^{\star \star \star}$ \\
\hline $\mathrm{Fe}^{2+}$ chelation & $993.68 \pm 50.74$ & EDTA & $1.27 \pm 0.05^{\star \star \star}$ \\
\hline
\end{tabular}

\section{Figure 3.}

Effect of the $70 \%$ methanolic extract of Elaeagnus latifolia Linn. (ELME) and standard ascorbic acid in the DPPH radical scavenging study. The results are mean \pm S.D. $(n=6)$. ${ }^{\star \star *}: P<0.001$ vs. $0 \mu \mathrm{g} \cdot \mathrm{mL}^{-1}$.

\section{Figure 4.}

Hydroxyl radical scavenging activity of $70 \%$ methanolic extract of Elaeagnus latifolia Linn. (ELME) and the reference compound mannitol. The results are mean \pm S.D. $(n=6)$ ${ }^{* *}: P<0.01$ and ${ }^{* * *}: P<0.001$ vs. $0 \mu \mathrm{g} \cdot \mathrm{mL}^{-1}$.
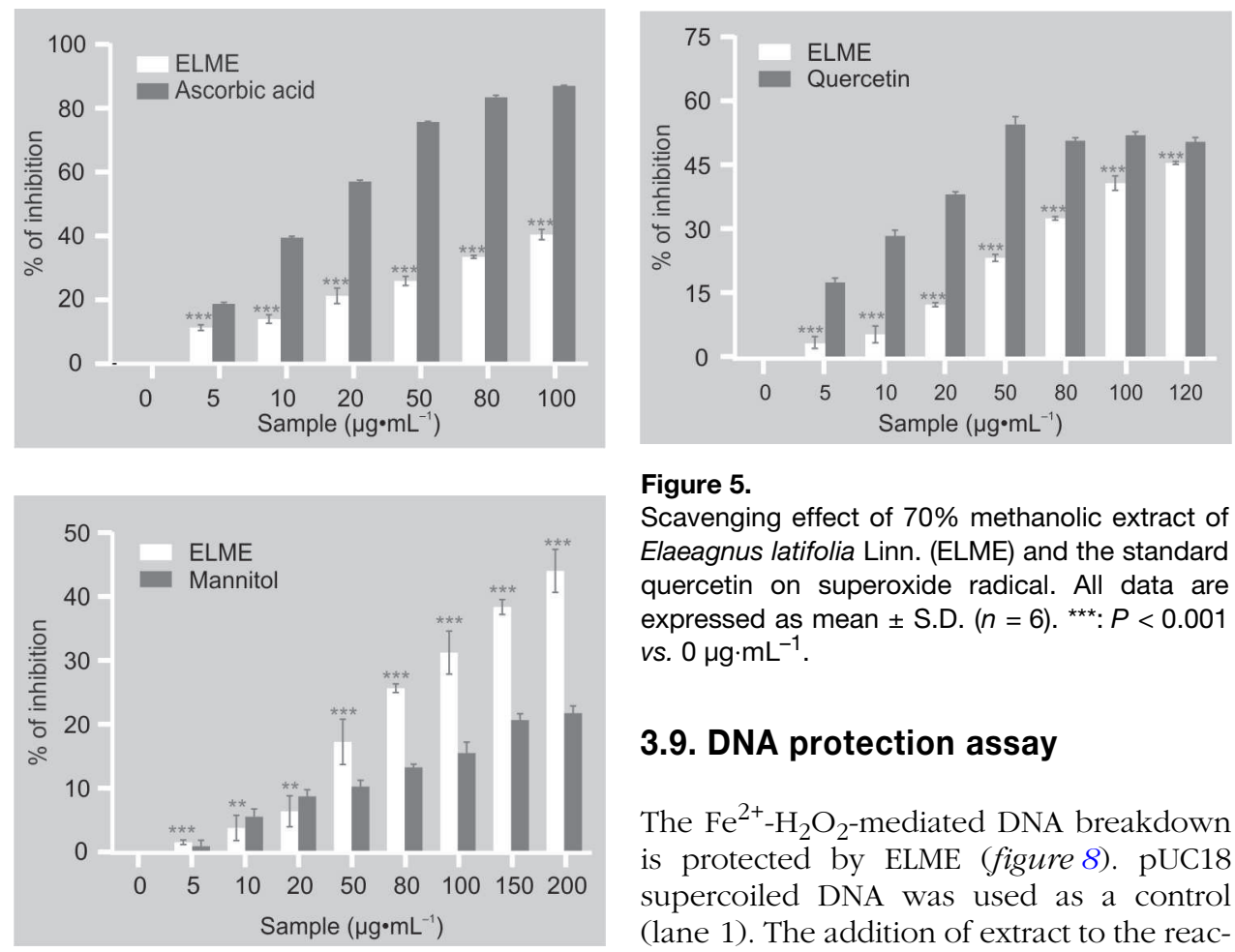

results, the extract was not as efficient as the standard EDTA, but the decrease in the concentration-dependent colour formation in the presence of the extract indicates that it has iron-chelating properties.

\section{Figure 5.}

Scavenging effect of $70 \%$ methanolic extract of Elaeagnus latifolia Linn. (ELME) and the standard quercetin on superoxide radical. All data are expressed as mean \pm S.D. $(n=6)$. ${ }^{\star \star *}: P<0.001$ vs. $0 \mu \mathrm{g} \cdot \mathrm{mL}^{-1}$.

\subsection{DNA protection assay}

The $\mathrm{Fe}^{2+}-\mathrm{H}_{2} \mathrm{O}_{2}$-mediated DNA breakdown is protected by ELME (figure 8). pUC18 supercoiled DNA was used as a control (lane 1). The addition of extract to the reaction mixture substantially decreased the DNA strand scission in a dose-dependent manner, leading to the protection of DNA under oxidative stress. The treatment of supercoiled DNA with Fenton's reagent led to the conversion of DNA to the open circular form (lane 2). The addition of different 


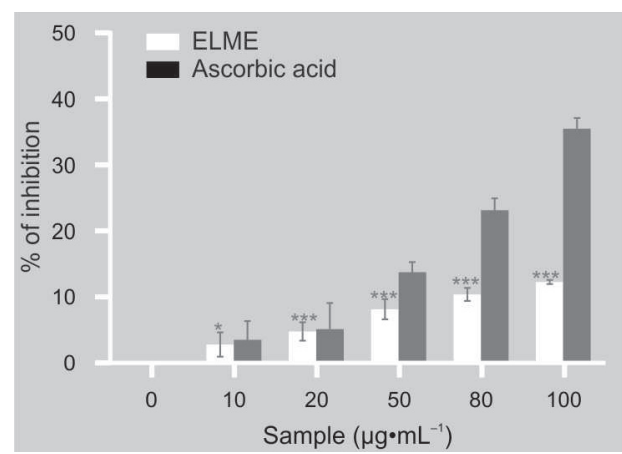

Figure 6.

Hypochlorous acid scavenging activity of $70 \%$ methanolic extract of Elaeagnus latifolia Linn. (ELME) and the standard ascorbic acid. All data are expressed as mean \pm S.D. $(n=6)$. ${ }^{*}: P<0.05$ and ${ }^{* \star}: P<0.001$ vs. $0 \mu \mathrm{g} \cdot \mathrm{mL}^{-1}$.

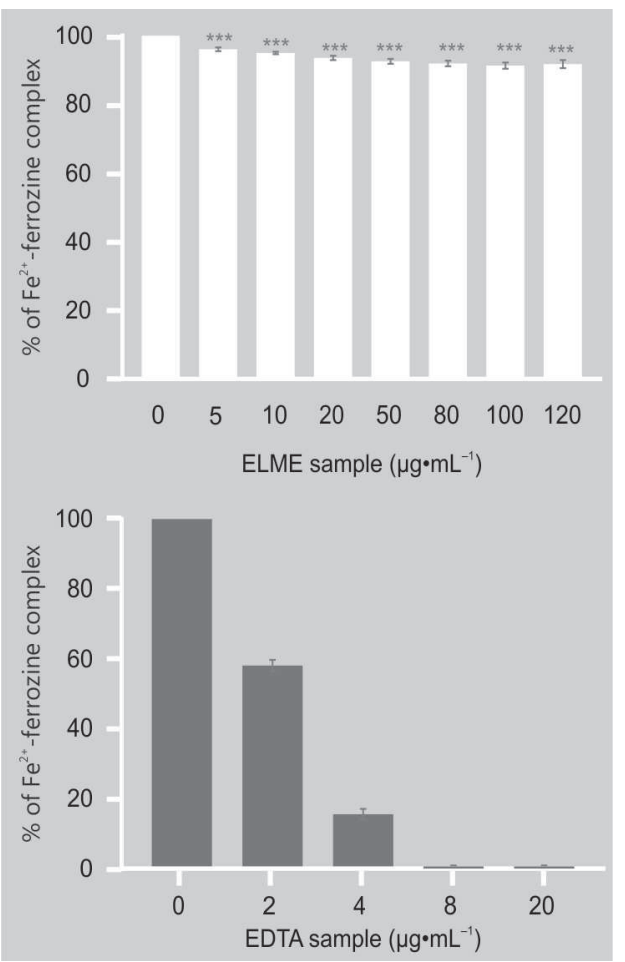

Figure 7.

Effect of $70 \%$ methanolic extract of Elaeagnus latifolia Linn. (ELME) (above) and the standard EDTA (below) on ferrozine- $\mathrm{Fe}^{2+}$ complex formation. The results are mean \pm S.D. $(n=6)$. ${ }^{* * *}: P<0.001$ vs. $0 \mu \mathrm{g} \cdot \mathrm{mL}^{-1}$.

concentrations of an extract resulted in the restoration of DNA in the supercoiled form (lane 3 to 9). The significant reduction in the formation of nicked DNA and increase in supercoiled DNA in the presence of the extract determined its excellent DNA protective effect; also reflected by the $[\mathrm{P}]_{50}$ value (concentration of the extract required for $50 \%$ protection of the supercoiled DNA), which was found to be $(695.91 \pm 15.84) \mu \mathrm{g} \cdot \mathrm{mL}^{-1}$ (table II). DNA protection can be achieved by two pathways, either $\mathrm{Fe}^{+}$chelation or hydroxyl radical scavenging. In our study ELME did not have good $\mathrm{Fe}^{+}$chelation properties. So, ELME protects DNA through hydroxyl radical scavenging.

\subsection{Assays showing no significant results}

ELME extract did not showed any significant remarkable result in the nitric oxide, hydrogen peroxide, peroxynitrite, singlet oxygen scavenging, reducing power or lipid peroxidation inhibition assays, so the corresponding results and figures are not provided.

\section{Conclusions}

From the present study, we can conclude that a $70 \%$ methanolic extract of Elaeagnus latifolia contains small amounts of phenols, flavonoids, ascorbic acid, carbohydrates and tannins. Various in vitro assays indicate that the extract exhibits moderate antioxidant and free radical scavenging activities and, hence, the fruit is considered to be a significant source of natural antioxidants, which might be helpful in preventing the progress of oxidative stress in the body system. Therefore, further studies should be carried out to isolate active compounds from this fruit material with antioxidant properties.

\section{Acknowledgements}

The authors would like to thank $\mathrm{Mr}$. Rhitajit Sarkar and Dr. Bibhabasu Hazra for critically reviewing the paper. The authors also extend their thanks to Mr. Ranjit Kumar Das and Mr. Pradip Kumar Mallick for 


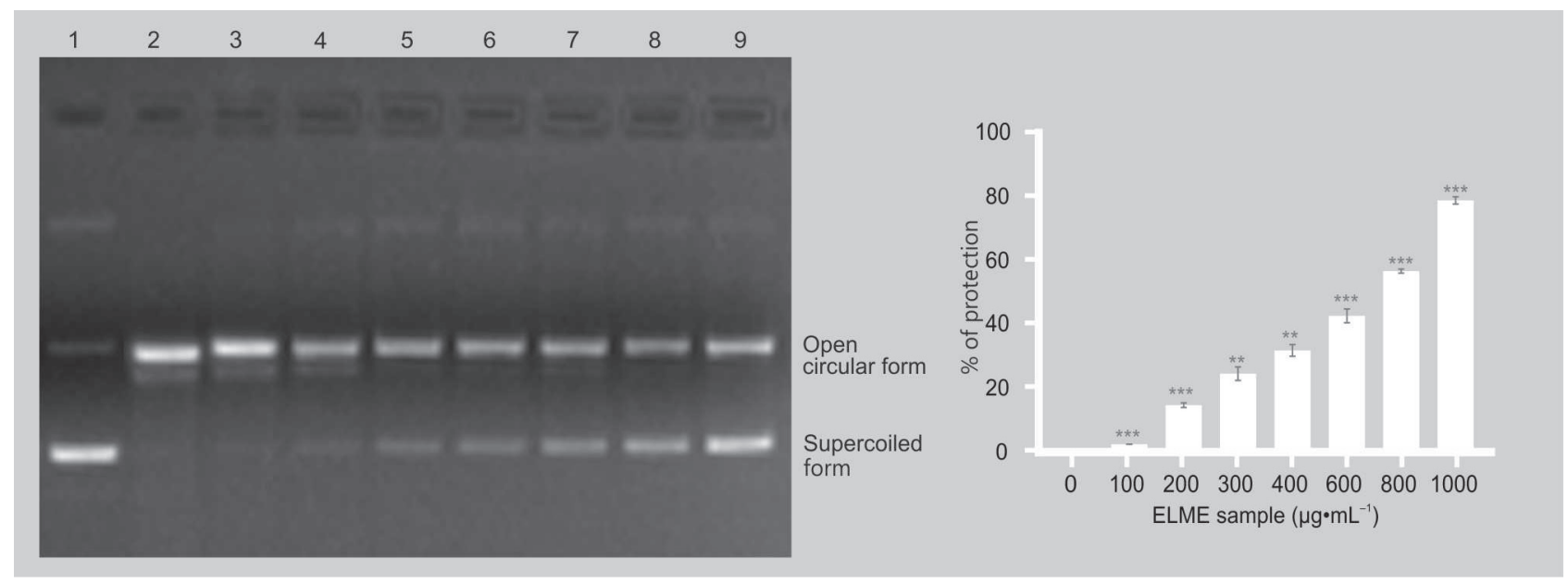

Figure 8.

Protection against oxidative damage to pUC 18 by $70 \%$ methanolic extract of Elaeagnus latifolia Linn. (ELME). Picture of agarose gel of pUC18 DNA showing bands of supercoiled and open circular forms. Lanes on the gel represent: (Lane 1) control DNA (no $\mathrm{H}_{2} \mathrm{O}_{2}$ or $\mathrm{Fe}^{2+}$ ); (Lane 2) reaction mixture without extract; (Lanes 3-9) reaction mixture with extract of increasing concentration (100$\left.1000 \mu \mathrm{g} \cdot \mathrm{mL}^{-1}\right)$. Each value represents mean \pm S.D. $(n=6)$ ${ }^{* *}: P<0.01$ and ${ }^{* *}: P<0.001$ vs. $0 \mathrm{mg} \cdot \mathrm{mL}^{-1}$. technical assistance in sample preparation and handling of lab equipment and animals in experimental procedures.

\section{References}

[1] Tiwari A., Imbalance in antioxidant defence and human disease: multiple approach of natural antioxidants therapy, Curr. Sci. 81 (2001) 1179-1187.

[2] Henle E.S., Linn S., Formation, prevention, and repair of DNA damage by iron/hydrogen peroxide, J. Biol. Chem. 272 (1997) 1909519098.

[3] Marnett L.J., Oxyradicals and DNA damage, Carcinogenesis 21 (2000) 361-370.

[4] Retsky K.L., Freeman M.W., Frei B., Ascorbic acid oxidation product(s) protect human low-density lipoprotein against atherogenetic modification. Anti-rather than prooxidant activity of vitamin $C$ in the presence of transitionmetal ions, J. Biol. Chem. 268 (1993) 1304-1309.

[5] Braca A., Sortino C., Politi M., Morelli I., Mendez J., Antioxidant activity of flavonoids from Licania licaniaeflora, J. Ethnopharmacol. 79 (2002) 379-381.

[6] Macedo L.F., Rogero M.M., Guimarães J.P., Granato D., Lobato L.P., Castro I.A., Effect of red wines with different in vitro antioxidant activity on oxidative stress of high-fat diet rats, Food. Chem. 137 (2013) 122-129.

[7] Alezandro M.R., Granato D., Genovese M. I., Jaboticaba (Myrciaria jaboticaba (Vell.) Berg), a Brazilian grape-like fruit, improves plasma lipid profile in streptozotocin-mediated oxidative stress in diabetic rats, Food. Res. Int. 54 (2013) 650-659.

[8] Kahl R., Kappus H., Toxicology of the synthetic antioxidants BHA and BHT in comparison with the natural antioxidant vitamin $\mathrm{E}, \mathrm{Z}$. Lebensm. Unters. Forsch. 196 (1993) 329338.

[9] Patel R.K., Singh A., Deka B.C., Soh-Shang (Elaeagnus latifolia): an under-utilized fruit of north east region needs domestication, ENVIS, Bull. Himalayan Ecol. 16 (2008) 1-2.

[10] Harborne J.B., Baxter H., Moss G.P., Phytochemical dictionary: a handbook of bioactive compounds from plants, Taylor \& Francis Ltd., London, U.K., 1999.

[11] Kokate C.K., Purohit A.P., Gokhale S.B., Test book of Pharmacognosy, Nirali Prakashan, Pune, India, 2003.

[12] Das A., Chaudhuri D., Mandal N., Chatterjee A., Study of antioxidant and reactive oxygen species scavenging activity of the edible tuber of "Greater Yam" (Dioscorea alata L.) from North-East India, J. Asian Pharm. Clin. 5 (2012) 74-84.

[13] Ghate N.B., Chaudhuri D., Mandal N., In vitro assessment of Tinospora cordifolia stem for its antioxidant, free radical scavenging and DNA protective potentials, Int. J. Pharm. Bio. Sci. 4 (2013) 373-388.

[14] Chaudhuri D., Ghate N.B., Sarkar R., Mandal N., Phytochemical analysis and evaluation of antioxidant and free radical scavenging activity of Withania somnifera root, Asian J. Pharm. Clin. Res. 5 (2012) 193-199.

[15] Sarkar R., Hazra B., Mandal N., Anti-oxidative protection against iron overloadedinduced liver damage in mice by Cajanus 
cajan (L.) Millsp leaf extract, Indian J. Exp. Biol. 51 (2013) 165-173.

[16] Hazra B., Sarkar R., Biswas S., Mandal N., Antioxidant and iron chelating potential of Pongammia pinnata and its role in preventing free radical induced oxidative damage in plasmid DNA, Int. J. Phytomed. 3 (2011) 240-253.

[17] Hazra B., Biswas S., Mandal N., Antioxidant and free radical scavenging activity of Spondias pinnata, BMC Compl. Altern. Med. 8 (2008) 63.

[18] Beckman J.S., Chen H., Ischiropulos $H_{\text {. }}$ Crow J.P., Oxidative chemistry of peroxynitrite, Meth. Enzymol. 233 (1994) 229-240.

[19] Hermes-Lima M., Nagy E., Ponka P., Schulman H.M., The iron chelator pyridoxal isonicotinoyl hydrazone $(\mathrm{PIH})$ protects plasmid pUC18 DNA against $\mathrm{OH}$-mediated strand breaks, Free Rad. Biol. Med. 25 (1998) 875-880.

[20] Finkel T., Holbrook N.J., Oxidants, oxidative stress and the biology of ageing, Nature 408 (2000) 239-247.

[21] Rop O., Mlcek J., Jurikova T., Sochor J., Kizek R., Antioxidant properties of saskatoon berry (Amelanchier alnifolia Nutt.) fruits, Fruits 68 (2013) 435-444.

[22] Lim Y.S., Lee S.S.H., Tan B.C., Antioxidant capacity and antibacterial activity of different parts of mangosteen (Garcinia mangostana Linn.) extracts, Fruits 68 (2013) 483-489.

[23] Yildirim A., Mavi A., Oktay M., Kara A.A., Algur O.F., Bilaloglu V., Comparison of antioxidant and antimicrobial activities of tilia (Tilia argentea Desf ex DC), sage (Savia triloba L.), and black tea (Camellia sinensis) extracts, J. Agric. Food Chem. 48 (2000) 5030-5034.

[24] Kessler M., Ubeaud G., Jung L., Anti- and pro-oxidant activity of rutin and quercetin derivatives, J. Pharm. Pharmacol. 55 (2003) 131-142.

[25] Weisburger J.H., Eat to live, not live to eat, Nutrition 16 (2001) 767-773.

[26] Jesus N.Z.T., Falcao H.S., Gomes I.F., Leite T.J.A., Lima G.R.M., Barbosa-Filho J.M., Tavares J.F., Silva M.S., Athayde-Filho P.F., Batista L.M., Tannins, peptic ulcer and related mechanisms, Int. J. Mol. Sci. 13 (2012) 3203-3228.

[27] Pickhardt M., Gazova Z., Bergen V.M., Khlistunova I., Wang Y., Hascher A., Mandelkow E.M., Biernat J., Mandelkow E., Anthraquinones inhibit tau aggregation and dissolve Alzheimer's paired helical filaments in vitro and in cells, J. Biol. Chem. 280 (2005) 3628-3635.
[28] Jeremić S.R., Šehović S.F., Manojlović N.T., Marković Z.S., Antioxidant and free radical scavenging activity of purpurin, Monatsh. Chem. 143 (2012) 427-435.

[29] Gülçina İ., Huyutb Z., Elmastaşc M., Hassan Y.A.E., Radical scavenging and antioxidant activity of tannic acid, Arab. J. Chem. 3 (2010) 43-53.

[30] Zhang M., Swarts S.G., Yin L., Liu C., Tian Y., Cao Y., Swarts M., Yang S., Zhang S.B., Zhang K., Ju S., Olek D.J.J., Schwartz L., Keng P.C., Howell R., Zhang L., Okunieff P., Antioxidant properties of quercetin, Adv. Exp. Med. Biol. 701 (2011) 283-289.

[31] Kosanović M.M., Šeruga M., Jakobek L., Novak I., Electrochemical and antioxidant properties of $(+)$-catechin, quercetin and rutin, Croat. Chem. Acta 83 (2010) 197-207.

[32] Begum S., Naqvi S.Q., Ahmed A., Tauseef S., Siddiqui B.S., Antimycobacterial and antioxidant activities of reserpine and its derivatives, Nat. Prod. Res. 26 (2012) 20842088.

[33] Koleva I.I., Van Beek T.A., Linssen J.P.H., deGroot A., Evstatieva L.N., Screening of plant extracts for antioxidant activity: a comparative on three testing methods, Phytochem. Anal. 13 (2002) 8-17.

[34] Goyal A.K., Mishra T., Bhattacharya M., Kar P., Sen A., Evaluation of phytochemical constituents and antioxidant activity of selected actinorhizal fruits growing in the forests of Northeast India, J. Biosci. 38 (2013) 797-803.

[35] Halliwell B., Reactive oxygen species in living systems: Source, biochemistry, and role in human disease, Am. J. Med. 91 (1991) S14-S22.

[36] Aruoma O.I., Halliwell B., Hoey B.M., Butter J., The antioxidant action of $\mathrm{N}$-acetylcysteine: Its reaction with hydrogen peroxide, hydroxyl radical, superoxide, and hypochlorous acid, Free Rad. Bio. Med. 6 (1989) 593-597.

[37] Usoh I., Akpan E., Etim E., Farombi E., Antioxidant action of dried flower extracts of Hibiscus sabdariffa $L$. on sodium arseiteinduced oxidative stress rats, Pak. J. Nutr. 4 (2005) 135-141.

[38] Dennis W.H., Olivieri V.P., Krusé C.W., The reaction of nucleotides with aqueous hypochlorous acid, Water Res. 13 (2003) 357-362.

[39] Carr A.C., Vissers M.C., Domigan N.M., Winterbourn C.C, Modification of red cell membrane lipids by hypochlorous and haemolysis by preformed lipid chlorohydrins, Redox Rep. 3 (1997) 263-271. 


\section{Evaluación in vitro de los compuestos fitoquímicos, de los antioxidantes y del potencial protector del ADN de los frutos silvestres comestibles de Elaeagnus latifolia Linn.}

Resumen - Introducción. Elaeagnus latifolia Linn. es un tipo de fruto silvestre comestible, que se encuentra en el norte de la India, en Tailandia, así como en Vietnam. A pesar de que el fruto se considere una fuente de vitaminas, minerales, ácidos grasos esenciales y otros compuestos bioactivos, sólo existen pocas investigaciones sobre la actividad antioxidante de esta planta. Material y métodos. Nuestro estudio reveló la actividad antioxidante y el potencial de captación de los radicales in vitro de pulpa de Elaeagnus latifolia Linn. extraída con la ayuda de una solución acuosa de metanol al 70 \% (ELME). Se realizaron diversos tests, entre los cuales la identificación y la cuantificación de compuestos fitoquímicos, de la actividad total antioxidante, del radical hidroxilo, del radical superóxido y de oxígeno singlete, así como ensayos del poder reductor y de captación del ácido hipocloroso y de la protección del ADN. Resultados y discusión. Entre los tests realizados, el radical superóxido captado de ELME $\left[\mathrm{IC}_{50}=(150.78 \pm 4.2) \mu \mathrm{g} \cdot \mathrm{mL}^{-1}\right]$, el radical hidroxilo $\left[\mathrm{IC}_{50}=(238.09 \pm 11.63) \mu \mathrm{g} \cdot \mathrm{mL}^{-1}\right] \mathrm{y}$ el ADN pUC18 protegido $\left[\mathrm{P}_{50}=(695.91 \pm 15.84) \mu \mathrm{g} \cdot \mathrm{mL}^{-1}\right]$ presentaron una protección eficaz. El fruto resulta ser una fuente de ínfimas cantidades de hidratos de carbono, de ácido ascórbico, de taninos, de compuestos fenólicos y de flavonoidos. Los datos HPLC mostraron que la purpurina, el ácido tánico, la quercetina, la catequina, la reserpina y rutina se encontraban presentes en los extractos (ELME) presentes. Conclusión. Nuestros resultados aportan una prueba de que el extracto de E. latifolia Linn. actúa como un antioxidante prometedor al igual que como protector del $\mathrm{ADN}$, lo que se debe, en parte, a los compuestos fenólicos y flavonoides que le componen.

India / Elaeagnus latifolia / frutas / propiedades medicinales / radicales libres / antioxidantes 